\title{
Social Movement Activism Analysis of Strategic Communication in Context
}

https://doi.org/10.21814/uminho.ed.46.5

\section{Robert L. Heath ${ }^{1}$ \& Damion Waymer ${ }^{2}$}

1 Department of Communication, University of Houston, Houston, United States of America; ${ }^{2}$ Department of Advertising and Public Relations, College of Communication and Information Sciences, University of Alabama, Alabama, United States of America ${ }^{1}$ https://orcid.org/0000-0002-7754-5629; ${ }^{2}$ https://orcid.org/0000-0002-5530-535X 



\begin{abstract}
Social movement activism presumes strategic communication processes by which groups achieve extra-governmental changes to public and private policy through public pressure. Such pressure presumes conditions of five kinds: strain, mobilization, confrontation, negotiation, and resolution. To explain this process, several cases will be offered but especially the U.S. civil rights movement and the activist career of John Lewis. Social movement activism is a test of wills, a test of character, strength, fact, value, identity, identification, and place.
\end{abstract}

\title{
Keywords
}

social movement activism, strain, mobilization, confrontation, negotiation, resolution

\section{Social Movement Activism: Analysis of Strategic Communication in Context}

Perhaps no strategic communication topic is more appealing to the discussion of political economy, social justice, self-determination, civil society, and self-governance than activism, short for social movement activism. Including social movement under the conceptual umbrella of strategic/ strategy is valuable because activism is collective action, a communitarian (grassroots) rhetorical rationale and context for strategic communication (Heath, 2018) and public relations (Bourland-Davis et al., 2010; Smith \& Ferguson, 2001, 2010) designed to change some aspect of society from outside of the establishment.

Recent news out of Hong Kong has featured efforts, for instance, by citizens to blunt the regulatory influence of the Beijing government. Citizens of Hong Kong adore the prospects of maintaining their self-determination, their self-government against what they believe to be a big, oppressive government located in Beijing. Much quieter is the citizenry of Taiwan, which is watching Hong Kong closely worried that its own autonomy will also be denied. It is drawing on the Hong Kong example to know how, and whether, to invoke social movement activism. The secession movement in Catalonia, Spain, aspires for self-governance independent of Madrid. Strategic communication as the expression of activism is a tool used to seek constructive, and preferably, collaborate change. 
These current examples are among the few. As will be developed later in this chapter, the civil rights movement in the USA is an iconic example of strategic communication as social movement activism. This movement is updated by the "Black Lives Matter" movement. Such efforts, rhetorical applications of strategic communication, reach back to the golden age of Greece, when discourse processes were set into theoretical perspective by Socrates, Aristotle, and Isocrates. In this tradition, activism results from the organization, management, and strategic communication of issue positions that challenge the legitimacy of hegemonic institutions, often referred to as "the establishment". Whereas in ancient Greece, the right and responsibility to speak was constituted as male citizenship. It was orderly and privileged.

Activism might be privileged, but also it might entail what Boyd and VanSlette (2009) called "outlaw discourse". Although the strategic communication of activists employs the standard argument-response approach, it also may "eschew such conventional, recognizable methods" (Boyd \& VanSlette, 2009, p. 328). "Outlaw discourse employs a logic that, when translated into the dominant system, is deemed illogical, immoral, or illegal" (Boyd \& VanSlette, 2009, p. 333). One might, for instance, presume that the strategic communication expressed through sit-ins at segregated lunch counters is illogical, at least, and perhaps immoral, and was interpreted as illegal. But, does the textuality of a sit-in say we will endure injustices, injury, and insults as the enactment of change? Tolerating peacefully such injustices provides knowledge about the character of the activists and those who seek to condemn their public action. Such outlaw acts ask the question, does peaceful protest demonstrate the illogic and injustice of segregation?

The central theme is the ability of activism to achieve engagement. Engagement can be viewed from a dominant organization or institution's point of view, self-interest. It also can be understood as grassroots activism. As such, activists' effort to engage may be unfulfilled, unreciprocated. Thus, "the value of activism as an engagement approach is that activists are seen for what they do, not what organizations do in response to activists or how organizations can co-opt activism" (Saffer, 2018, p. 288). "Shared meaning and social capital are two outcomes of engagement impact, activists' efficacy" (Saffer, 2018, p. 288).

In this heritage, one most dear to the authors of this chapter occurred in the late 18th century, when the 13 loosely affiliated colonies of British America planned, argued for, and accomplished independence and self-governance. Central to that effort was the statement of grievances justifying 
independence: the Declaration of Independence. Since gaining its freedom, the United States of America has been a country that endures and predominantly tolerates social movement activism as a strategic communication means by which citizens shape their relationship with one another, their government's policies, free enterprise organizations and non-governmental organizations, such as the National Rifle Association. From its inception as colonies, and the introduction of slavery, one of the enduring themes of social movement activism is the nature of freedom, independence, and self-determination. Relevant to African Americans, the Southern states engaged, through social movement activism, to create a confederacy intended to maintain the institution of chattel slavery; that led to civil war. Counter to the agitation to maintain slavery was the continuing effort to end the institution of slavery, before and after the civil war. Although the civil war and three amendments to the U.S. constitutions ostensibly ended oppression of African Americans, the years between the end of the war, 1865, to today have witnessed continued social movement activism regarding the status of those citizens.

Starting in the late 1860 s, social movement activism dedicated to White supremacy began to reject the principles of African American freedom and self-determination asserted by the union over the south. That rejection, a White supremacy social movement, used activism to reassert hegemonic control over African Americans; that movement led to oppression which motivated the counter activism of the civil rights movement of the 20th century. That movement gained renewed impetus after World War II (WWII), especially vibrant in the 1960s. Also, 2020 marks the 100th anniversary of women's suffrage in the USA. So as has often been observed, social movement activism is as American as apple pie!

As social movement activism, strategic communication fits the rhetorical paradigm (as opposed to an information theory paradigm) as it is collective incentivization to action based on strategic choices to influence followers and opponents to change by challenging hegemony. As such, strategic communication is discourse/text (in all of its dimensions) facilitating collective, collaborative decision-making. It seeks agreement in opposition to disagreement as conflict issues management. Strategy is choice-driven communicative actions regarding types of influence relevant to individual, group, relational, community, and societal existentialism. It engages the definition and redefinition of people, relationships, power, community, and society. 
In light of its status in U.S. culture, this work offers an explanation and examination of activism as strategic communication, or the strategic communication aspects of activism. Thus, the first part of the chapter provides a detailed, conceptual, and theoretical explanation of the strategic communication processes of activism. Although various examples may be offered along the way, the second major section of the work will focus on the activism of, and on behalf of, African American citizens, especially in the legacy of the honorable John Lewis (1940-2020), who was a civil rights icon for more than 50 years (Meacham, 2020). He left a legacy of courage in the face of death to achieve change through non-violence. That is a fitting legacy and useful theme in the chapter, since social movement activism is not always non-violent. It, as are most topics of strategic communication, is multi-dimensional, multilayered, and multi-textual. Inherently rhetorical, it is essentially dialectical - the push and shove of defined issue positions and interest against defined interest (Heath, 1973b). It is extra-governmental because it presumes the need for change, which is not occurring sufficiently through government or is being opposed by government. It asks the strategic communication question of how can people change their community, their society, through discourse - and other means?

\section{Activism as the Strategic Communication of Managing Change in Context}

Often associated with the concept of "grassroots" ("bottom up" struggle against a hegemony), activism is traditionally seen as people exerting pressure from outside the established power structure of society (Heath, 2018, pp. $2-3)$. As such, a sense of marginalization offers the incentive and rhetorical rationale for change. However, it is quite conceivable that the powerful can use activism against "activists". This can be done when the powerful instrumentalize a segmented public to its interest or even presents itself as victim.

Developing a corporate strategic communication view of activism, Grunig (1992) reasoned that the presence of activism groups "makes the environment of organizations most turbulent" (p. 503). Consequently, she reasoned, public relations managers need to be in place to help others in management interact constructively with activists. Her analysis is based on Olson's (1982) theory of collective action, which looks upon activism through the lens of pressure groups. Activist groups aspire and work to change the organization's policies from the outside. This outsider paradigm presumes that activists need to know how and be able to gain and exert power because, 
as outsiders, they do not have it as their intrinsic role in organizational life or society. They do so by making issues out of problems. For these reasons, Grunig (1992) argued, taking an inside-looking out at activist groups approach, that public relations' role in management is a means for collaboration, rather than collision, with activists.

Holtzhausen (2007) adopted a similar perspective but featured it as strategic outside-looking-in communication. By such means, she reasoned, public relations practitioners can support management by acting as internal activists, on behalf of external activists, exploring the means, methods, and rationale for constructive change. As much as both the Grunig (1992) and Holtzhausen (2007) theses could be seen as constrictively supporting efforts of social movement activism, they could as well be seen as coopting, mitigating, and even stifling efforts, such as civil rights, as they collide with corporate hegemony.

Emphasizing the possibility of co-optation (and not limited to issues salient with African American interests), Smith (2005) noted:

co-optation is a strategy used by dominant institutions or organizations to respond to and eventually neutralize activists who threaten to disrupt the dominant group. The strategy takes a variety of forms, but essentially the more powerful organization creates the appearance that they share the less powerful group's aims and grants some concessions or shares power with the less powerful group. (p. 196)

The strategic outcome is the appearance of change without that reality either in issue position or power sharing. Ostensible dialogue may in actuality be monologue. Issue position and power sharing are two central aspects of the strategic communication of social movement activism.

The 1960s in the USA was a robust era of social movement activism. It was studied by sociology, social psychology, political science, and communication scholars. They agreed that a grievance rationale, the recognition of problems as strains, provided the rationale for activism (Alinsky, 1971; Gamson, 1968, 1975; Griffin, 1952; Moe, 1980; Oberschall, 1973, 1978; Olson, 1982; Simons, 1970, 1972, 1974; Smelser, 1963; Toch, 1965). This claim, among others, supported Heath and Nelson's (1986) exploration of strategic issues management as a practitioners' and scholars' approach to understanding the strategic communication means by which social movement activism is a vital part of societal public policymaking. Centered on the incentive driven 
communicative and managerial processes of social conflict as collective action, activism was viewed as rational problem-solving behaviors capable of collaborative outcomes. As Heath (2018) noted, "activism is a genre of communication, and activists organize to communicate, and communicate to organize" (p. 2). Moloney and McKie (2016) emphasized Saul Alinsky's (1971) disruptive paradigm as a constructive turn in public relations.

This exploration led to a modeling of social movement activism on the assumption that it is the rhetorical rationale for collective, collaborative decision making, at least in principle if not prevalent in practice. Prevailing public relations philosophy tended to presume that advocacy (counter-advocacy) could blunt the criticism voiced by activists. It could even yield to pressure tactics, the exercise of hegemonic power. Activism was also viewed as illegitimate behavior insofar as it challenged the rationale of the established order. It could be illegal, criminal, and likely irrational. Opponents to activists often ask, "how dare they?".

The model Heath and Nelson (1986) proposed featured strain, a concept championed especially by Smelser (1963) as foundationally motivating. In addition to strain, the model featured mobilization (power gaining), confrontation (power using argumentation), negotiation, maintenance, and termination. About a decade later, truncated the model by assuming maintenance and featuring resolution instead of termination (Heath, 1997; Heath \& Palenchar, 2009). The improved five-factor model presumed a strategic arc from strain to resolution, the end of strain, the resolution of conflict. Strategic issue communication is vital to each of the five stages.

Strain presumes shared problem recognition: activists desire to change conditions that cause discomfort or prevent people from obtaining or enjoying advantages they believe they deserve. "A social movement represents an effort by a large number of people to solve collectively a problem that they feel they have in common" (Toch, 1965, p. 205). The feeding ground of activism is "the ranks of persons who have encountered problems" (Toch, 1965, p. 9). That logic fits the rationale for strategic change integrated in speech communication public speaking classes during the 20th century. Millions of students were prompted to build their speeches to feature a problem of relevance, shared by the audience, and propose a solution. The test of a solution's persuasiveness is its ability to solve the problem in ways that benefit, are agreeable to, the audience. 
Strain is motivational because it is intrinsically comparative: what is versus what is preferred, what ought to be (Smelser, 1963). In that regard, it is a rhetorical test of identity (Heath, 2012), identification, and place, associations people form to express their identities. For that reason, the aspirational goal of activism based on strain presumes some issue range between dissatisfaction and improved condition, perhaps a better answer to a corporate or public policy issue. It weighs what is against what could and should be as incentivized strategic communication. Activists gather information, through various kinds of research - often direct experience and lay observation; this is subjected to values analysis, judgments such as fairness, safety, equality, and environmental quality. In the case of civil rights, the facts put into play may be as harmful as lynching, as injustices at the ballot box, and as hidden as multivariate analysis of salary/wage, promotion, hiring, and safety in workplace practices. As strategic communication, activists isolate issues and point to choices (advantages versus disadvantages) as motivation for change. Individuals cherish "the images of society, of right and wrong, justice and injustice, success, and other moral components of their view of the world and where they themselves are situated in it" (Oberschall, 1973, pp. 83-84). That not only justifies activism, within communities, but it also serves to motivate and mobilize actions. Through strategic communication, strain incentivizes collective action; mobilization is the enactment of collective action.

Mobilization occurs when disparities between what is and what ought to be incentivize or motivate social movement collective behavior: organized activism. Such mobilization can translate into formal organization, even with officers and position/activity assignments. Such mobilization seeks to redistribute stakes from stakeholders to stakeseekers. Mobilization requires numbers of individuals with joined, purposeful actions. It is the gathering and deployment of power resources. It might, as will be seen in the case of civil rights, translate into marches and demands.

As such, mobilization is the manifestation of organized change management in the face of resistance. Such resistance may range from police violence to very subtle use of research and deliberation, planning and programming change to appear to be committed to and achieving change, as smoke and mirrors. It is not unlikely, especially the case with 1960s civil rights that the mobilization of conflicting interests leads to clashes that become violent. As such, social movement activism tests willingness to risk as an establishment vulnerability (Heath, 1979). Dominant society presumes that, perhaps through policing, it can raise a threshold of risk of bodily 
harm that activists will not cross. But what if they cross that threshold, as civil rights marchers did, at the Edmund Pettus Bridge, on "bloody Sunday", March 7, 1965 (Klein, 2020; Meacham, 2020)? That clash was heard around the globe. It marked the moment of high risk taking necessary to translate mobilization into confrontation.

If mobilization creates a focalized tension on issue positions, confrontation occurs. Confrontation is a test of wills, a test of character, strength, fact, value, identity, identification, and place. Confrontation may occur in the streets, in media content, in court, in the court of public opinion and public interest. Skilled activists confront to narrow the options and opinion positions of their opponents. Confrontation is dialectical, discursive. It frames issues and operates from frames to present arguments and to advance as well as deny power. It is, as Kenneth Burke $(1968,1969)$ reasoned, the tension between merger and division. It is the rhetoric of identification which appeals as courtship, the invitation to share issue positions, preferences, identities, identification, and place. Burke's (1969) theory of language offers rationale for strategic communication in general and social movement activism in specific. It depends on terms for reality/positive terms (terms about things/ experience, reality), dialectical terms (terms the meaning of which is based on opposites/opposition: freedom/tyranny, justice/injustice), and ultimate (God, unitary, and overarching) terms (those that people act in the name of, freedom, for instance).

Confrontation can be purely terministic, the expression of division, or communicatively demonstrative. As in the case of the violent abolitionist, John Brown, his "violence jarred a nation into action, but violence can only succeed if it achieves legitimacy through earned social capital, that being the public relations challenge facing terrorists and their supporters" (Heath \& Waymer, 2014a, p. 209). Confrontation, however peaceful, reasonable, dramatic, or violent, is a test of character and social capital. It asks, can society advance to produce gains, social capital - these sought-after values and outcomes? It is demonstrable that John Brown was hanged for an individual act of terrorism (as he attempted to abolish slavery in the USA) which he believed was justified by his religious Calvinism. In contrast, Jefferson Davis (president of the Confederate States of America) was not hanged for his attempt at the violent overthrow of the U.S. government (as he fought to preserve the institution of slavery in the USA); Davis was widely lauded throughout the south. Monuments, schools, roads, and such were placed and named in his honor (Heath \& Waymer, 2014a, 2014b). Activists' discursive, 
textual search is for knowledge, values, identity, identification, and place needed to create a fully functioning society.

Because of the nature of language, the layeredness of meanings, dialectical terms become elevated to be ultimate terms. This means that they can transcend division and achieve merger. As Burke (1969) concluded, "there must be a principle of principles involved in such a design - and the step from principles to a principle of principles is likewise both a fulfillment of the previous order and the transcending of it" (p. 189; see also Heath, 1973b). The inherent logic of Burke's (1969) theory of language is that terms, as terministic screens (defining and attitudinizing reality), operate definitionally and evaluatively, adjusting individual and collective minds - and perceived/interpreted reality. As Heath (1973b) observed,

confrontation demands that the people involved transcend the level at which there is division. Upward movement resolves division and establishes new identifications and priorities. In transcendence there is purification as the nonessential and divisive elements are eliminated or revalued in priority. (p. 171)

Rhetorical clash is not only a contest of merger and division, but also an invitation (courtship) to consider a different perspective for organizing society. Such rhetorical dialectic is foundational to strategic communication because "ideally the dialogue seeks to attain a higher order of truth, as the speakers, in competing with one another, cooperate towards an end transcending their individual positions" the reconciliation of differences as a higher synthesis (Burke, 1969, p. 53).

Presuming that confrontation sufficiently pushes those who hold competing perspectives, then differences can be, need to be, reconciled. Difference is harmful to self-determination. Society cannot easily balance issue positions at odds with one another. Thus, negotiation is a concerted search for order in the face of unproductive disorder. It is a kind of "deal striking", striking a deal, making a collective, win-win decision. One of the daunting aspects of social movement activism is that negotiation may fail if it presumes a common ground, a mid-point in differences. Thus, if the issue of civil rights activism is the right to vote, a partial, conditional right to vote may not be, and likely is not a negotiable answer to "the right to vote". In fact, the Reconstruction, Jim Crow answer to voting often was an impediment that was supposed to be a tolerable half measure. So, voting was not a citizenship right but the result of the ability of some people to get over a 
hurdle which often was never a level playing field; the bar was higher for African Americans to vote than for White European Americans.

Compromise might suffice as negotiation. But it might not. If negotiation presumes that both sides can and must be satisfied, that conclusion misses the strategic communication dynamics of confrontation. Negotiation may presume capitulation by one side to the other. That logic reaches back in American society to the years after the civil war when White supremacists refused to accept the war's outcome, including three constitutional amendments. Equality, equal treatment under the law, was a half measure even in the face of demonstrated capability to aspire, lead, and achieve (Heath, 1975). Negotiation failed to bring social tranquility between 1865 and 1955 because equality, equal treatment under the law, was not achieved during this time period. Thus, strain existed for mobilization and confrontation to continue or reemerge as the contest of social cohesion and social justice.

If negotiation succeeds and division gives way to merger, then the voices in social movement activism can and have achieved resolution. The test of resolution is whether the changes agreed upon become the new hegemony. If not, or to the extent not, strain continues to be an incentive for calls to change, to mobilize and to confront.

Strategic communication as social movement activism is most relevantly examined and enacted in context. The incentivizing strain is contextual, as is mobilization, confrontation, negotiation, and resolution. For instance, social movement activism has opposed the oil production industries practices of fracking (Ferguson \& Smith, 2012a, 2012b; Ferguson et al., 2016; Smith \& Ferguson, 2013).

The strategic communication of social movement activism is the enactment of angst driven existentialism. It presumes the potential social capital of co-created meaning as the rationale for a new relational hegemony (Saffer, 2018). It asks how should we act toward one another in ways that constructively manage change in the aura of transcendent textual perspectives? That has been the question surrounding the shared meaning and social capital of African Americans in U.S. society. That point can be better understood by a brief case analysis of the civil rights movement especially viewed through the experience of the recently departed, John Lewis, the last of those featured speakers at the historic August 1963 march on Washington (National Geographic, n.d.) - one who had his skull cracked during the aforementioned mobilization turned confrontation at 
the Edmund Pettus Bridge. His mantra was the right of all citizens to vote as the highest form of self-determination.

As this section has featured a five-part model, the case that follows will demonstrate how that model is issue or topic sensitive. Social movement activism, especially in the case of African American social justice is older than the U.S. civil war, was reinvigorated after the war as White supremacy launched its own renewed social movement activism. The case that follows picks up that narrative in the 1960 s.

\section{African American Social Movement Activism}

Although this section focuses primarily on the civil rights movement post WWII in the USA, a couple of glimpses are worth noting regarding this issue. Almost from the introduction of Africans in bondage to Jamestown in 1619, critics of this labor and commercial practice collided with opponents who believed that God abhorred slavery. Consequently, the antislavery movement was the first concerted effort to combat slavery which became set in stone by the U.S. Constitution, particularly the $3 / 5$ clause and the requirement that slaves fleeing their condition must be returned to their owners. The civil war partially settled this matter, once a coalition of radical republicans and a few civil rights leaders such as Frederick Douglass successfully passed three constitutional amendments. All of that happened because of sustained social movement activism. In the United States, colonists' activism led to the war of independence; the new nation that was created was soon challenged by "democratic activism": the Whiskey Rebellion, Shaw's Rebellion, anti-slavery activism, states' rights secessionism, and Jim Crowism.

Importantly, however, immediately after the civil war, White Southerners set about re-imposing control over Black labor to restore the old order. This mobilization was pressed by social movement activists such as those that created the Ku Klux Klan and eventually the Sons of Confederate Soldiers and Daughters of the Confederacy. These latter activist groups not only fought for labor, economic, political, and social restrictions on African Americans but also shaped southern culture based on the lost cause principle that the south would rise again to achieve White dominance and states' rights freedoms of local determination. These social movement tactics of racial superiority are not unique, as Adolph Hitler also began his political career and climb to power as a social movement activist (Range, 2016). 
Because the problem is White supremacy, that is the starting point of African American civil rights social movement activism. White supremacy is the immoveable object against which African American civil rights activism is an irresistible force. Some might say that Christianity, the dominant religion that espouses one God, one faith, one baptism for all (the Jew and gentile alike) in the USA would mitigate the oppressive nature of White Americans towards non-White Americans, particularly African Americans. Jones (2020) argued the opposite: "the Christian denomination in which I grew up was founded on the proposition that chattel slavery could flourish alongside the gospel of Jesus Christ. Its founders believed this arrangement was not just possible but also divinely mandated" (p.x). It is telling that more than 5 decades ago, Dr. Martin Luther King Jr. used principals of Christian theology with varying degrees of success in his attempts to find common ground with White American Christians on the issues of racial reconciliation and justice with and for African Americans (Tisby, 2018). A key point in this process is that the rhetorical dialectic of social movement activism is argumentative, adversarial, and assertive. Even as it presumes to challenge opponents over values, it can fail because of the poverty of values, their fluidity and ambiguity. One might assume that in a nation dedicated to freedom that value would be universally rather than contextually applied to public decision making (Heath, 1973a).

As noted above, it is reasonable to see the civil rights movement created and energized by African Americans was in fact a counter movement, counter activism. Reflecting on the roots of oppression, Jones (2020) concluded:

while the South lost the war, this secessionist religion not only survived but also thrived. Its powerful role as a religious institution that sacralized white supremacy allowed the Southern Baptist Convention to spread its roots during the late nineteenth century to dominate southern culture. (p. 2)

That awareness of church influence has created awareness of White European origin citizens that they must join in support of African American civil rights and must work to make their churches and local communities inclusive (Waymer \& Cripps, 2018); thus, African American civil rights as social movement activism is a White problem as well as an African American problem, one needing reconciliation and change (Jones, 2020; see also Lee, 2019).

WWII brings us closer to the time when the contemporary civil rights movement aspired to end White hegemony. African American soldiers fought 
against the tyranny of nazism, fascism, and imperial Japan. Segregation was often the status in military ranks. One of the most blatant racist societal and military policies was not allowing blood from Black service personnel to be administered to White service personnel (Guglielmo, 2015). But, after the war, military forces (as had been the case after WWI when African American soldiers were lynched in uniform) returned to civilian life and sought equal treatment under the law. Many restrictions prevailed, such as prohibition against inter-racial marriage, but none was more odious than legislative, judicial, and administrative restrictions of voting. Science, pseudo-science (such as phrenology and false correlation) provided what researchers interpreted as moral, intellectual, and physical limitations based on race (Jones, 2020; Wilder, 2013). Voting is the ultimate empowerment, or disempowerment, because it is the root of sociopolitical power, and African American voting rights were restricted severely due to perceived race-based inferiority.

The White supremacy movement revitalized in the 1870 s as the White south reeled from the reality of the end to chattel slavery instantiated into law based on three constitutional amendments: 13, 14, and 15. Under Reconstruction overseen by the union government, former states' elections placed African Americans into positions of political power, such as lieutenant governors, U.S. senators and representatives as well as their state counterparts. Federal occupation and "negro rule" were sources of strain. White Leagues and citizens' councils (they have many names such as White Magnolia and the Ku Klux Klan) formed to mobilize and confront the change brought about by the end of the civil war. Riots occurred. Murdered African Americans were buried in anonymous graves; White activist militants killed in riots had monuments placed in their honor (Jones, 2020). Lynching became the most overt form of disempowerment, but thousands of others, including disenfranchisement and segregation (separate and unequal), prevailed from the 1870s well into the 20th century. Increased knowledge of lynching motivated W. E. B. DuBois to expand his scholarship to include analysis of, and action against social injustice. The overt oppression of poll taxes, voter preparedness tests, and simple denial of the right to vote have been eradicated in principle, but in practice covert "modern" forms of vote(r) suppression in the 21st century exist such as gerrymandering (Waymer \& Heath, 2016) and voter ID laws amongst others (Ofer \& Robinson, 2020). White supremacy is the textual strain that calls for mobilization and confrontation in the search for negotiation and resolution.

Thus, a new phase in the African American social movement started by focusing on gaining the universal franchise. The legislation following the civil 
war had granted the vote, but its full social capital, advantages, access, and privileges were elusive. This began the modern social movement activist era made iconic by leaders such as Martin Luther King Jr. and John Lewis. Lewis was a new generation member of Martin Luther King Jr's civil rights era; one of the "big six" speakers at the March on Washington (National Geographic, n.d.). A documentary based on his life named John Lewis: Good Trouble (Porter, 2020) details how he was born into poverty, in a family which told him to avoid trouble, but he began his life of service committed to "get in good trouble". The kind that produced good results (Meacham, 2020; Newkirk, 2018; Porter, 2020). He was introduced to the service of civil rights while in college by one of his instructors, Reverend James Lawson. He served as chairman of the Student Nonviolent Coordinating Committee from 1963-1966. He served in the U.S. House of Representative for 16 terms and authored many bills relevant to civil rights, especially voter rights (Porter, 2020).

The making of this civil rights activist began in Troy, Alabama, when a young Lewis, aspiring to be a preacher, experienced overt and covert racism with his family (Meacham, 2020; Porter, 2020). They were willing to be patient, not to cause trouble, but Lewis became motivated to make trouble in the cause of social justice. Early in life, he recognized the strain of social injustice, such as the prevalence of separate public facilities such as drinking fountains, public bathrooms, and store entrances. He realized that as much as such strain can be expressed in generalized, value laden terms, it also needs to be expressed in specific, accomplishable and measurable achievement.

As a college student in Nashville, Tennessee, he was part of the Nashville Student Movement which focused, in part, on equal treatment at lunch counters in downtown Nashville following the trend started by students in Greensboro, North Carolina (Porter, 2020). As a member of the Nashville Student Movement (mobilization) in conjunction with the Nashville Christian Leadership Council (part of the Southern Christian Leadership Council), he participated in sit-in's at lunch counters asking only to be served at the same part of the counter and with the same dignity and respect as White customers. The call (strain, mobilization, and confrontation) was for direct action (specific and measurable). They were committed to the philosophy (as was Mahatma/Mohandas Gandhi) and confrontational strategy of nonviolence. The students targeted various stores, in teams, but the most visible (to photojournalism and video/TV) was lunch counters. Students would take advantage of several seats together at a counter. Take those seats. Place orders. They would be told they could not sit there or place orders. They refused to leave. They were willing to get in "good trouble". They knew they 
would be abused by White onlookers. They might have cigarettes put into their hair, catsup put on their clothes, and such. Over 150 students were eventually arrested for disorderly conduct (although they had not been "disorderly"). They were ordered to move by police and then escorted to jail when they did not. The students who had been arrested were found guilty and fined.

Such confrontation led to negotiation and eventually resolution, when the mayor of Nashville said he favored desegregation, at least in part because nonviolence was giving way to and motivating violence, including the fire-bombing of the students' lawyer's home. Large numbers of marchers came to city hall demanding change. Out of the confrontation, came negotiation which led to six stores agreeing to serve African American customers at lunch counters. Only after, and because of the Civil Rights Act of 1964, did more desegregation occur (Porter, 2020).

The Nashville students were motivated by workshops conducted by a local pastor, Reverend James Lawson, who learned about and studied nonviolence when serving as a missionary in India in the 1950s. Lawson was influenced by other civil rights leaders who believed that White Americans would resist nonviolent tactics less than violent tactics (Bliss, 2020). Peaceful demonstration called attention to issues, strains, more clearly than violence did. Even then it had consequences. Lawson, who was enrolled in Vanderbilt University's Divinity School, was criticized in the local papers as a troublemaker, for inciting students to engage in disorderly conduct. Lawson was told to cease his involvement with the students, an order he refused to obey. Ultimately, he was expelled from Vanderbilt; many White American students protested his expulsion deeming such action unfair (Bliss, 2020). His firm stand for racial justice and social activism alongside his expulsion motivated many more ministers and religious groups to become involved (Bliss, 2020). Such new strain, motivated additional mobilization and confrontation. This issue had clearly become one of faith, religious, and church teaching, Jesus, Gandhi, and contemporaneously, Martin Luther King Jr.

In the full picture of the civil rights movement, it is imprecise to portray Reverend Lawson in a frame that is too large, but his alumni became leaders which spread out and built followings and legacies of their own (Vanderbilt University, 2019). He used the concept of "satyagraha" as a rationale for the power of nonviolence, as did Gandhi. Martin Luther King Jr. incorporated Gandhi's philosophy into his writings, research, and teachings and championed it as a morally efficacious concept in social protest, the 
concept that nonviolence is a truth-force as a love-force (King, 1958). Satyagraha invites positive regard as reciprocation for positive regard. As the students were warned, violence breeds violence; so, when protesters' nonviolence provoked violence (especially in police officers) that demonstrated the higher moral ground of peaceful protest, and the willingness to suffer for doing and believing in moral righteousness. One can argue that negotiation and resolution are easier accommodation motives than the militant resistance provoked by violent protest.

In many respects the sit-ins are a classic case of strategic communication as social movement activism in context. However, to stop the case here would miss the contextuality of the larger issue of civil rights and the deadly challenges that were both central to the civil rights movement and John Lewis' life. To focus more on those details, we need to examine voting rights activism, which turned violent and even deadly. To demonstrate the strain of voting rights, to mobilize and confront, 600 people met in Selma, Alabama to begin a march to Montgomery to demonstrate the need for voter rights. The march was several months in the planning. Hosea Williams of the Southern Christian Leadership Council and John Lewis of Student Nonviolent Coordinating Committee led the march (Porter, 2020). They were the first to confront, or to be confronted by some 150 Alabama state troopers at the Edmund Pettus Bridge that would have to be crossed. It was a physical and symbolic barrier to the activists' mobilization. A trooper announced over a bull horn, "this march will not continue". Mr. Williams asked the lead trooper to engage in conversation. "Mr. Major, I would like to have a word, can we have a word?" "I've got nothing further to say to you", Cloud answered (Porter, 2020).

Major Cloud of the Alabama troopers ordered the troopers to move toward the marchers, who were beaten and knocked down. Mr. Lewis had his skull broken. He remembered being beaten. As those images, captured in photography, television, and words went public, that strategic communication gave legislators (and others) who supported voting rights the evidence of police violence and moral authority to pass legislation, making it a federal offense to deny the right to vote based on the color of a citizen. President Lyndon Johnson was able to leverage the bill, and then sign it (Porter, 2020).

As much as supporters would like 45 years later to believe that matter is settled, it is not. The U.S. Supreme Court ruled that parts of the voter rights bill are no longer needed (Shelby County v. Holder, 2013). Twenty-five states have passed bills designed to restrict voting rights (Brennan Center 
for Justice, 2019). A new and improved (given the Supreme Court ruling) bill passed the House of Representatives and in 2020 awaits action by the Senate and President (Human Rights Campaign, 2021). All of which demonstrates that after confrontation, through negotiation that if resolution fails, strain continues. As a fitting aside, the aforementioned bill has been reintroduced by senator Leahy as the John Lewis Voting Rights Advancement Act (S. 4263) to honor the late civil rights hero and voting rights champion (Human Rights Campaign, 2021).

\section{Conclusion}

Strategic communication is choice-driven communicative actions regarding types of influence relevant to individual, group, relational, community, and societal existentialism. The existentialism in this context focuses on the identity and identification of customers at lunch counters and at voter registration drives and at marches to combat voter restriction. What is the existential nature of lunch counter customers and voters? What texts, levels of terministic perspectives, define the identity, identification, and narratives needed for a fully functioning society? What ultimate terms define, guide, and elevate dialectical terms and positive terms?

More than an information theory, flow, paradigm of communication, strategic communication presumes that meaning and messaging are paramount factors in human association. If language is, therefore, the essence of strategic communication, flaws in language and meaning are both the rationale for strategic communication and its challenge. As Burke (1934) insightfully concluded: "if language is the fundamental instrument of human cooperation, and if there is an 'organic flaw' in the nature of language, we may well expect to find this organic flaw revealing itself though the texture of society" ( $p$. 330). In context, and in this case social movement activism, terms are an incentive and a means of strategic communication. Communities are divided by language, by meaning. Social movement activists use strategic communication to create wounds (divisions in society) and heal them (unity and merger).

\section{References}

Alinsky, S. (1971). Rules for radicals: A practical primer for realistic radicals. Random House.

Bliss, J. (2020, March 4). You will not fight back: The Rev. James Lawson's nonviolent teachings led to his expulsion from Vanderbilt 60 years ago. The Tennessean. https://www.tennessean.com/story/news/politics/2020/03/04/james-lawson-expelled-vanderbilt-role-1960-sit-ins/4806723002/ 
Bourland-Davis, P. G., Thompson, W., \& Brooks, F. E. (2010). Activism in the 20th and 21st centuries. In R. L. Heath (Ed.), The Sage handbook of public relations (pp. 409-420). Sage Publications.

Boyd, J., \& VanSlette, S. H. (2009). Outlaw discourse as postmodern public relations. In R. L. Heath, E. L. Toth, \& D. Waymer (Eds.), Rhetorical and critical approaches to public relations II (pp. 328-342). Routledge.

Brennan Center for Justice. (2019, October 1). New voting restrictions in America. https://www. brennancenter.org/our-work/research-reports/new-voting-restrictions-america

Burke, K. (1934). The meaning of C. K. Ogden. New Republic, 78, 328-331.

Burke, K. (1968). Language as symbolic action. University of California Press.

Burke, K. (1969). A rhetoric of motives. University of California Press.

Ferguson, D. P., \& Smith, M. F. (2012a). No frackin' way: Activism in the Marcellus Shale region. Business Research Yearbook, 18(1), 497-504.

Ferguson, D. P., \& Smith, M. F. (2012b). What the frack? Activism in the Marcellus Shale region. International Journal of Interdisciplinary Research, 7(2), 14-35. https://www.researchgate.net/ publication/288950381_What_the_Frack_Activism_in_the_Marcellus_Shale_region

Ferguson, D. P., Smith, M. F., \& Efird, B. (2016). Measuring the impact of U.S. activism and policy decisions on hydraulic fracturing policy globally. Quarterly Review of Business Disciplines, 3(2), 81-100. https://faculty.utrgv.edu/louis.falk/qrbd/QRBDaug16.pdf\#page=9

Gamson, W. A. (1968). Power and discontent. Dorsey.

Gamson, W. A. (1975). The strategy of social protest. Dorsey.

Griffin. L. M. (1952). The rhetoric of historical movements. Quarterly Journal of Speech, 38(2), 184-188. https://doi.org/10.1080/00335635209381762

Grunig, L. A. (1992). Activism: How it limits the effectiveness of organizations and how excellent public relations departments respond. In J. E. Grunig (Ed.), Excellence in public relations and communication management (pp. 503-530). Lawrence Erlbaum.

Guglielmo, T. A. (2015, February 12). Desegregating blood: A civil rights struggle to remember. The Conversation. https://theconversation.com/desegregating-blood-a-civil-rights-struggle-to-remember-37480

Heath, R. L. (1973a). Black rhetoric: An example of the poverty of values. Southern Speech Communication Journal, 39(2), 145-160. https://doi.org/10.1080/10417947309372224

Heath, R. L. (1973b). Dialectical confrontation: a strategy of black radicalism. Central States Speech Journal, 24, 168-177. https://doi.org/10.1080/10510977309363166

Heath, R. L. (1975). Alexander Crummell and the strategy of challenge by adaptation. Central States Speech Journal, 26(3), 178-187. https://doi.org/10.1080/10510977509367841 
Heath, R. L. (1979). Risk as a dimension of social movement vulnerability. In D. Nimmo (Ed.), Communication yearbook 3 (pp. 491-505). Sage Publications.

Heath, R. L. (1997). Strategic issues management: Organizations and public policy challenges. Sage Publications.

Heath, R. L. (2012). Was black rhetoric ever anything but race in public relations? The challenge of the rhetoric of identity. In D. Waymer (Ed.), Culture, social class, and race in public relations: Perspectives and applications (pp. 225-244). Lexington Books.

Heath, R. L. (2018). Activism. In R. L. Heath \& W. Johansen (Eds), The international encyclopedia of strategic communication (pp. 1-14). John Wiley \& Sons.

Heath, R. L., \& Nelson, R. A. (1986). Issues management: Corporate public policymaking in an information society. Sage Publications.

Heath, R. L., \& Palenchar, M. J. (2009). Strategic issues management: Organizations and public policy challenges 2. Sage Publications.

Heath, R. L., \& Waymer, D. (2014a). John Brown, public relations, terrorism, and social capital: 'His truth goes marching on'. Public Relations Inquiry, 13, 209-226. https://doi. org/10.1177/2046147X14539697

Heath, R. L., \& Waymer, D. (2014b). Terrorism: Social capital, social construction and constructive society? Public Relations Inquiry, 3(2), 227-244. https://doi.org/10.1177/2046147X14529683

Holtzhausen, D. R. (2007). Activism. In E. L. Toth (Ed.), The future of excellence in public relations and communication management (pp. 357-379). Lawrence Erlbaum.

Human Rights Campaign. (2021, March 22). John Lewis voting rights advancement act. https:// www.hrc.org/resources/voting-rights-advancement-act

Jones, R. P. (2020). White too long: The legacy of White supremacy in American Christianity. Simon \& Schuster.

King, M. L., Jr. (1958). My pilgrimage to nonviolence. https://kinginstitute.stanford.edu/king-papers/documents/my-pilgrimage-nonviolence

Klein, C. (2020, July 18). How Selma's 'bloody Sunday' became a turning point in the Civil Rights Movement. History. https://www.history.com/news/selma-bloody-sunday-attack-civil-rights-movement

Lee, R. W. (2019). A sin by another name: Reckoning with racism and the heritage of the south. Convergent.

Meacham, M. J. (2020). His truth is marching on: John Lewis and the power of hope. Random House.

Moe, T. M. (1980). The organization of interests. University of Chicago Press. 
Moloney, K., \& McKie, D. (2016). Changes to be encouraged: radical turns in PR theorization and small-step evolutions in PR practice. In J. L'Etang, D. McKie, N. Snow, \& J. Xifra (Eds.), The Routledge handbook of critical public relations (pp. 151-161). Routledge.

National Geographic. (n.d.). March on Washington. https://www.nationalgeographic.org/media/ march-washington/student/print/

Newkirk, V. R. (2018). How Martin Luther King Jr. recruited John Lewis. The Atlantic. https://www. theatlantic.com/magazine/archive/2018/02/john-lewis-martin-luther-king-jr/552581/

Porter, D. (Director). (2020). John Lewis: Good trouble [Film]. ACG Studios; CNN Films; Time Studios.

Oberschall, A. (1973). Social conflict and social movements. Prentice-Hall.

Oberschall, A. (1978). The decline of the 1960s social movements. In L. Kriegsberg (Ed.), Research in social movements, conflict, and change: An annual compilation of research (pp. 257-289). JAl.

Ofer, U., \& Robinson, J. (2020, December 7). Bold and visionary: A criminal justice to-do list for the new administration. Aclu. https://www.aclu.org/news/smart-justice/bold-and-visionary-a-criminal-justice-to-do-list-for-the-new-administration/

Olson, M. (1982). The logic of collective action. Public goods and the theory of groups. Harvard University Press.

Range, P. R. (2016). 1924: The year that made Hitler. Little, Brown.

Saffer, A. J. (2018). The outcomes of engagement in activism networks: A co-creational approach. In K. A. Johnston \& M. Taylor (Eds.), The handbook of communication engagement (pp. 285-299). John Wiley \& Sons.

Shelby County v. Holder, 570 U.S. 529 (2013).

Simons,H.W.(1970). Requirements, problems, and strategies:Atheory of persuasion for social movements. Quarterly Journal of Speech, 56(1), 1-11. https://doi.org/10.1080/00335637009382977

Simons, H. W. (1972). Persuasion in social conflicts: A critique of prevailing conceptions and framework for future research. Speech Monographs, 39(4), 227-247. https://doi. org/10.1080/03637757209375763

Simons, H. W. (1974). The carrot and stick as handmaidens of persuasion in conflict situations. In G. R. Miller \& H. W. Simons (Eds.), Perspectives on communication in social conflict (pp. 172-205). Prentice Hall.

Smelser, N. J. (1963). Theory of collective behavior. Free Press.

Smith, M. F. (2005). Co-optation. In R. L. Heath (Ed.), Encyclopedia of public relations (pp. 196197). Sage Publications.

Smith, M. F., \& Ferguson, D. P. (2001). Activism. In R. L. Heath (Eds.), Handbook of public relations (pp. 291-300). Sage Publications. 
Smith, M. F., \& Ferguson, D. P. (2010). Activism 2.0. In R. L. Heath (Ed.), The Sage handbook of public relations (pp. 395-407). Sage Publications.

Smith, M. F., \& Ferguson, D. P. (2013). "Fracking democracy": Issue management and locus of policy decision-making in the Marcellus Shale gas drilling dispute. Public Relations Review, 39(4), 377-386. https://doi.org/10.1016/j.pubrev.2013.08.003

Tisby, J. (2018, January 15). Why so many white churches resisted Martin Luther King Jr.'s call. The Washington Post. https://www.washingtonpost.com/news/acts-of-faith/wp/2018/01/15/ why-so-many-white-churches-resisted-martin-luther-king-jr-s-call/

Toch, H. (1965). The social psychology of social movements. Bobbs-Merrill.

Vanderbilt University. (2019, February 7). Rev. James Lawson. https://www.vanderbilt.edu/trailblazers/2019/02/07/rev-james-lawson/

Waymer, D., \& Cripps, R. (2018). “Coming up the rough side of the mountain”: Building a multicultural church in a us southern, historically White mill town. In K. M. Morant \& O. Banjo (Eds.), Contemporary Christian culture: Messages, missions, and dilemmas (pp. 111-125). Peter Lang.

Waymer, D., \& Heath, R. L. (2016). Black voter dilution, American exceptionalism and racial gerrymandering: The paradox of the positive in political public relations. Journal of Black Studies, 47(7), 635-658. https://doi.org/10.1177/0021934716649646

Wilder, C. S. (2013). Ebony and ivy: Race, slavery, and the troubled history of america's universities. Bloomsbury Press. 